\title{
Development of Osmotic Dehydrated Aonla (Emblica officinalis, Gaertn)
}

\author{
Meenakshi Tyagi* and S.S. Dhawan \\ Centre of Food Science and Technology, Chaudhary Charan Singh Haryana Agricultural \\ University, Hisar, Haryana, India \\ *Corresponding author
}

\begin{tabular}{|c|c|}
\hline \multicolumn{2}{|r|}{ A B S T R A C T } \\
\hline & \multirow{6}{*}{$\begin{array}{l}\text { The present study was undertaken to standardize the optimum process for osmotic } \\
\text { dehydration of aonla and to evaluate the nutritional and organoleptic quality during } \\
\text { processing and storage. Eight treatments were given with different combination of } \\
\text { blanching }(\mathrm{Bl}) \text {, sulphuring }(\mathrm{S}) \text {, osmosis in sugar }(\mathrm{Os}) \text {, osmosis in sugar and glycerol and } \\
\text { then dried at } 65^{\circ} \mathrm{C} \text { and then stored at room temperature for } 60 \text { days. Physical and chemica } \\
\text { characteristics of fresh fruits were recorded at } 0,30 \text { and } 60 \text { days. Maximum moisture was } \\
\text { found in treatment } \mathrm{Bl}+\mathrm{S}+\mathrm{O} \text { s }(8 \mathrm{hr}) \text { and it decreased during storage. Ascorbic acid values } \\
\text { were significantly higher in treatment } \mathrm{Bl}+\mathrm{S}+\mathrm{Os} \text { ( } 8 \mathrm{hr}) \text { and were found to decrease } \\
\text { significantly during storage. Reducing sugar were found maximum in treatment } \mathrm{Bl}+\mathrm{S}+\mathrm{Os} \\
(8 \mathrm{hr}) \text { and an increase in reducing sugar content was observed during first month of storage } \\
\text { which decreased during second month. Total sugars were maximum in treatment } \mathrm{Bl}+\mathrm{O} \text { s } \\
\text { (16hr) and it decreased significantly during storage. Maximum tannins were found in } \\
\text { treatment with } \mathrm{Bl} \text { alone and tannin content decreased significantly during storage } \\
\text { Browning was minimum at the time of drying and then increased during storage. }\end{array}$} \\
\hline & \\
\hline $\begin{array}{l}\text { Osmotic dehydration, } \\
\text { Blanching, } \\
\text { Sulphuring, Browning. }\end{array}$ & \\
\hline Article Info & \\
\hline $\begin{array}{l}\text { Accepted: } \\
\text { 12 September } 2017 \\
\text { Available Online: } \\
10 \text { November } 2017\end{array}$ & \\
\hline & \\
\hline
\end{tabular}

\section{Introduction}

Aonla (Emblica officinalis, Gaertn), the Indian gooseberry belongs to family Euphorbiaceae and is known by several vernacular names such as Amalaki, Amla, Amlet, Amolphal, Aovla, Aurna, Chukna, Dhatriphala, Emblic myrobalan, Nelli and Sobju in different parts of the world (Agarwal and Chopra,2004). Aonla is a dry land fruit crop in U.P, H.R, Rajasthan and Punjab. Aonla fruit is probably the richest known source of ascorbic acid (Manny and Shadakshara swamy, 1997). Its ascorbic acid content has been reported to be about 300$1000 \mathrm{mg} / 100 \mathrm{~g}$ (Ghorai and Sethi, 1996). It is also rich in polyphenols (Gomez and Khurdiya, 2005) and other nutrients like pectin, fibre, carbohydrate, thiamine, riboflavin and carotene (Kumar et al., 2005). It is well known for its immense medicinal value and is therefore recommended by Ayurvedic and Unani system of medicines. Aonla fruit is highly perishable in nature and are difficult to store or transport over long distances, therefore it becomes necessary to preserve the fruit in the form of processed products. Drying is one of the oldest technique for the preservation of fruits and vegetables. Unlike other fruits the Vitamin $\mathrm{C}$ of aonla is not much destroyed on dehydration due to protection by tannins including gallic acid, ellagic acid and/or glucose present in it (Pragati, 1998). 
Osmotic dehydration, in which water is removed from fruit due to turgor pressure exerted by sugar syrup on fruit, provides a product with longer shelf life and good keeping quality (Adesina and Aina, 1990). It also results in quality improvement in terms of colour, flavour, texture, product stability, nutrient retention and prevention of microbial spoilage during storage (Tiwari, 2005).

It is a simpler technique which can be adopted even at rural areas without much investment and farmers can convert excess production into self-stable dehydrated form (Rashmi et al., 2005). Keeping in view the importance of fruit, the present study was undertaken to standardize the optimum process for osmotic dehydration of aonla and to evaluate the nutritional and organoleptic quality during processing and storage.

\section{Materials and Methods}

Studies were carried out at Department of Food Science and Technology, C.C.S. Haryana Agricultural University, Hisar in year 2007, to evaluate the most suitable treatment for osmo-air drying of aonla with maximum nutrient retention at the time of product formation and after storage of 30 and 60 days at room temperature.

Processing of aonla: Washing thoroughly with clean water and steeping in $2 \%$ salt solution for 3 days to remove astringency, then blanched for 8 minutes in boiling water containing alum to ease segment separation. Fruits were sulphured @ $5 \mathrm{~g} / \mathrm{kg}$ by burning powdered sulphur for 1 hour in closed chamber. Sugar steeping was done in sugar syrup of $70^{\circ}$ Brix for 8 hour and 16 hour for osmosis followed by drying in convectional air dryer $@ 65^{\circ} \mathrm{C}$ for $8-12$ hrs to make intermediate moisture product and then packed in polythene bags and sealed for further studies.
Various treatments were:

T1: Blanching T2: Blanching + Sulphured T3: Blanching + Osmosis (8 hour) T4: Blanching + Sulphured + Osmosis (8 hour) T5: Blanching + Osmosis (16 hour) T6: Blanching + Sulphured + Osmosis (16 hour) T7: Blanching + Osmosis (Glycerol- 16 hour) T8: Blanching + Sulphured + Osmosis (Glycerol- 16 hour)

\section{Nutritional evaluation}

Parameters analyzed were TSS (Abbe's refractometer), moisture content (AOAC, 1990), crude fibre and titratable acidity (Ranganna, 1986), Ascorbic acid (AOAC, 1990), sugar (Hulme and Narain, 1931), tannins (AOAC, 1990), organoleptic (Hedonic rating test - Ranganna, 1986) and statistical analysis in factorial completely randomized design (CRD) according to standard method is given in table 1 .

\section{Results and Discussion}

Effect of different drying treatments was studied on the nutritional quality of aonla after processing and storage period of 30 and 60 days at room temperature (Refer Tables 2 and 3). Moisture content was maximum in samples with treatment T4 and minimum in treatment T8. Moisture content significantly decreased on storage. Similar trend was also reported by Tripathi et al., (1988). Rani and Bhatia, (1986) also observed moisture loss in intermediate bagugosha (pear) samples.

Ascorbic acid was maximum in samples with treatment T4 and minimum in treatment T5. A significant decrease in ascorbic acid content was observed during storage. Kumar, (1990) also reported decrease in ascorbic acid content of papaya products during storage. Pathak, (1988) and Deen, (1992) also reported decrease in ascorbic acid content on storage. 
It has also been observed by Salunkhe and Desai, (1984); Singh et al., (2005) that ascorbic acid generally decreases on storage.
Reducing sugar content was maximum in treatment $\mathrm{T} 4$ and minimum in treatment $\mathrm{T} 1$ and $\mathrm{T} 2$.

\begin{tabular}{|l|l|}
\hline \multicolumn{2}{|c|}{ Table.1 Proximate analysis of fresh aonla fruit } \\
\hline Average fruit weight (g) & 32.3 \\
\hline Pulp (\%) & 87.6 \\
\hline Seed weight (\%) & 11.9 \\
\hline Moisture (\%) & 85.0 \\
\hline Total Soluble Solids (\%) & 9.0 \\
\hline Reducing Sugar (\%) & 6.28 \\
\hline Total Sugar (\%) & 7.5 \\
\hline Acidity (\%) & 2.7 \\
\hline Ascorbic acid (mg/100g) & 564 \\
\hline Crude fibre (\%) & 2.4 \\
\hline Tannin (mg/g) & 4.5 \\
\hline
\end{tabular}

\begin{tabular}{|l|l|c|c|c|c|c|c|c|c|c|c|c|}
\hline \multicolumn{10}{|c|}{ Table.2 Effect of treatment: and storage time on moisture, ascorbic acid, reducing sugar and total sugar of } \\
\end{tabular}


Table.3 Effect of treatment and storage time on tannin, browning and organoleptic attribute of dried aonla fruit stored at room temperature

\begin{tabular}{|c|c|c|c|c|c|c|c|c|c|}
\hline Treatment & \multicolumn{3}{|c|}{ Tannin $(\mathrm{mg} / \mathrm{g})$} & \multicolumn{3}{|c|}{ Browning (O.D at 440nm) } & \multicolumn{3}{|c|}{ Organoleptic attribute } \\
\hline & O Day & $\begin{array}{c}30 \\
\text { Days }\end{array}$ & $\begin{array}{c}60 \\
\text { Days }\end{array}$ & O Day & $\begin{array}{c}30 \\
\text { Days }\end{array}$ & 60 Days & 0 Day & 30 Days & 60 Days \\
\hline Bl (T1) & 7.0 & 6.2 & 5.7 & 0.129 & 0.137 & 0.143 & 5.2 & 5.7 & 4.0 \\
\hline BI + S (T2) & 6.7 & 4.3 & 3.0 & 0.049 & 0.064 & 0.072 & 5.2 & 5.5 & 4.3 \\
\hline Bl + Os (8hrs) (T3) & 5.0 & 3.5 & 1.4 & 0.038 & 0.056 & 0.062 & 7.2 & 6.0 & 6.1 \\
\hline Bl + S + Os (8hrs) (T4) & 5.1 & 3.7 & 1.5 & 0.059 & 0.066 & 0.071 & 7.1 & 6.4 & 6.2 \\
\hline Bl + Os (16hrs) (T5) & 5.6 & 3.7 & 2.5 & 0.053 & 0.071 & 0.092 & 7.4 & 6.4 & 7.0 \\
\hline $\begin{array}{l}\text { Bl + S + Os (16hrs) } \\
\text { (T6) }\end{array}$ & 6.2 & 4.3 & 3.0 & 0.097 & 0.127 & 0.140 & 7.2 & 7.3 & 7.3 \\
\hline $\begin{array}{l}\text { Bl + Os (Gly.16hrs) } \\
\text { (T7) }\end{array}$ & 6.5 & 5.6 & 3.7 & 0.096 & 0.109 & 0.121 & 7.2 & 7.1 & 7.3 \\
\hline $\begin{array}{l}\text { Bl + S + Os (Gly.16hrs) } \\
\text { (T8) }\end{array}$ & 6.8 & 5.4 & 4.2 & 0.132 & 0.281 & 0.292 & 7.1 & 7.2 & 7.5 \\
\hline C.D at $5 \%$ & \multicolumn{3}{|c|}{$\begin{array}{l}\text { Treatments }(T)=0.14 \\
\text { Storage }(\mathrm{St})=0.09\end{array}$} & \multicolumn{3}{|c|}{$\begin{array}{l}\text { Treatments }(\mathrm{T})=0.056 \\
\text { Storage }(\mathrm{St})=0.035\end{array}$} & \multicolumn{3}{|c|}{$\begin{array}{l}\text { Treatments }(T)=0.61 \\
\text { Storage }(S t)=\text { N.S }\end{array}$} \\
\hline
\end{tabular}

Reducing sugar increased up to 30 days of storage and then decreased significantly up to 60 days of storage, the reason behind this decrease might be that dehydration reactions causes sugar to become unsaturated and highly reactive (Fenemma, 1985). The results are similar to the findings of Pathak, (1988) who recorded an increase in reducing sugar during storage and Mehta, (1995); Kalsi, (1998) and Kumar, (1990) also reported increase in reducing sugar during storage of dehydrated aonla, guava products and papaya candy, respectively. Total sugar content was maximum in treatment $\mathrm{T} 5$ and minimum in treatment T1. No significant effect on total sugar content was observed in different treatments. Total sugar content was maximum at the time of drying and then significantly decreased during storage. Tripathi et al., (1988) and Basnett, (1992) also observed a decrease in total sugars in case of dehydrated aonla and carrot pickle respectively during storage. Tannin content was maximum in treatment $\mathrm{T} 1$ and minimum in treatment $\mathrm{T} 3$. Tannin content was maximum at the time of drying and then decreased significantly during storage. Mehta, (1995) also observed same decline in tannin content in aonla. Significant reduction in tannin content was also reported in bael preserve (Kaushik, 1997) and in processed sand pear products during storage (Baramanray, 1998). Minimum browning was observed in treatment T3. Browning was minimum at the time of drying and then increased during storage. Vashista, (1998) reported significant increase in browning of tomato products during storage. Rao and Roy, (1980); Chaddha, (1993) also observed enzymatic browning in mango sheets and guava products respectively. Organoleptic quality with 9 point hedonic scale evaluated that best accepted sample. Osmo-air drying was the best method for drying aonla fruits. Aonla fruit treated with treatment $\mathrm{T} 4$ were found to be best organoleptically and it had more nutrient retention with low tannins and less browning with improved taste and flavour.

\section{References}

A.O.A.C. 1990. Official methods of analysis: $14^{\text {th }}$ edn. Association of official analytical chemists, Washington, D.C. 
pp.125-139.

Adesina, A. A. and Aina, J.O. 1990. Preservation of African star apple fruit (Chrysophyllum albidum) by osmotic dehydration. Tropical Science. 30(3): 249-253.

Agarwal, S. and Chopra, C.S. 2004. Studies on changes in ascorbic acid and total phenol in making of aonla products. Bev. and Food World. 31(5): 32-34.

Baramanray, A. 1998. Studies on the processing technology of sand pear (Pyrus serotina Rehd. Var.culta) cv. Patharanakh. Ph.D thesis. CCS HAU, Hisar.

Basnett, B. 1992. Standardization and nutritional evaluation of some carrot products. M.Sc thesis, CCS HAU, Hisar.

Chaddha, M. 1993. Nutritional evaluation and utilization of guava pomace. M.Sc thesis, CCS HAU, Hisar.

Deen, B. 1992. Studies on screening of aonla (Emblica officinalis, Gaertn) genotype for processing. M.Sc thesis, N.D Univ. Of Agri and Tech., Faizabad (U.P).

Fenemma, R. 1985. Food chemistry. $2^{\text {nd }}$ edn., Marcel Dekker, Inc., New York and Basel.

Ghorai, K. and Sethi, V. 1996. Varietal suitability of Amla (desi and banarasi) fruit for storage and preservation. Ind. Food Pack. 50 (1): 11-18.

Gomez, S. and Khurdiya, D.S. 2005. Quality changes in aonla pulp under different storage conditions. Indian Food Pack. 59: 54-57.

Hulme, A.C. and Narain, R. 1931. The ferricyanide method for determination of reducing sugars. A modification of Hagedron Jensen-Hanes technique. Biochem. J., 25:1051-1056.

Kalsi, H. 1998. Development of dehydrated products of guava (Psidium guajava, L). M.Sc. thesis, CCS HAU, Hisar.

Kaushik, R.A. 1997. Studies on maturity indices and medicinal of fresh and preserved bael (Agele marmelos Correa) fruits. Ph.D thesis. CCS HAU, Hisar.

Kumar, S. 1990. Studies on post-harvest technology of papaya (Carica papaya, L.) fruit. Ph.D thesis. N.D University of Agri. and Tech., Faizabad (U.P).

Kumar, S., Kumar, A., Baig, M.J. and Chaubey, B.K. 2005. Effect of calcium on physico-chemical changes in aonla (Emblica officinalis, Gaertn). Ind. J. Hort., 64(4): 324-326.

Manny, N. and Shadaksharaswamy, M. 1997. Foods: Facts and Principles, $2^{\text {nd }}$ edn. New Age International (P) Ltd.,

Mehta, S. 1995. Evaluation of different cultivars of aonla (Emblica officinalis, Gaertn) for processing. M.Sc. thesis, CCS HAU, Hisar.

Pathak, S. 1988. Post harvest technology of aonla (Emblica officinalis, Gaertn) fruits. Ind. Food Pack., 49(4): 43-46.

Pragati. 1998. Nutritional quality of aonla (Emblica officinalis Gaertn) cv. Chakaiya as influenced by drying methods. M.Sc. thesis, CCS HAU, Hisar.

Ranganna, S. 1986. Handbook of analysis and quality control for fruit and vegetable products, $2^{\text {nd }}$ edn. Tata Mc Graw Hill Publishing Co. Ltd.,

Rani, U. And Bhatia, B.S. 1986. Studies on bagugosha pear for preserve and RTE products. Ind. Food Pack., 40 (3):25.

Rao, V.S. and Roy, S.K. (1980). Studies on dehydration of mango pulp. Standardization for making mango sheet/leather. Indian Food Packer. 34(3): 64-71.

Rashmi, H.B., Doreyappa Gowda, I.N. and Mukanda, G.K. 2005. Studies on osmoair dehydration of pineapple fruit. J.Food Technol. 42 (1): 64-66.

Salunkhe, D.K. and Desai, B.B. (1984). Postharvest Biotechnology of vegetables. Vol. 2. Pp.70-75. CRC Press, Inc. Boca 
Raton, Florida, USA.

Singh, B.P., Pandey, G., Sarolia, D.K., Pandey, M.K. and Pathak, R.K. 2005.

Shelf life evaluation of aonla cultivars. Ind. J. Hort., 62 (2): 137-140.

Tiwari, R.B. 2005. Application of osmo-air dehydration for processing of tropical fruits in rural areas. Ind. Food Industry. 24(6): 62-69.

Tripathi, V.K., Singh, M.B. and Singh,
S.1988. Studies on comparative compositional changes in different preserved products of amla (Emblica officinalis Gaertn) var. Banarasi. Ind. Food Pack, 42 (4): 60-65.

Vashista, A. 1998. Development of ready to drink tomato juice and instant soup from newly evolved tomato cultivars. M.Sc thesis, CCS HAU, Hisar.

\section{How to cite this article:}

Meenakshi Tyagi and Dhawan, S.S. 2017. Development of Osmotic Dehydrated Aonla (Emblica officinalis, Gaertn). Int.J.Curr.Microbiol.App.Sci. 6(11): 1369-1374. doi: https://doi.org/10.20546/ijcmas.2017.611.163 